\title{
HUBUNGAN POLA ASUH ORANG TUA DENGAN PERKEMBANGAN ANAK BALITA DI PAUD PERMATAKU PALU
}

\author{
Andi Fatmawati*, Fajrillah, Irna Woso \\ Poltekkes Kemenkes Palu Jurusan Keperawatan, Palu, Sulawesi Tengah, Indonesia \\ *) E-mail: fatmaandif@gmail.com
}

\begin{abstract}
ABSTRAK
Latar Belakang: Perkembangan yang dialami anak merupakan rangkaian perubahan yang teratur dari satu tahap perkembangan ke tahap perkembangan berikutnya yang berlaku secara umum. Orang tua merupakan sarana bagi anak untuk beradaptasi dengan lingkungan dan mengenal dunia sekitarnya serta pola pergaulan hidup yang berlaku di lingkungannya. Ini disebabkan orang tua merupakan dasar pertama bagi pembentukan pribadi anak. Bentuk-bentuk pola asuh orang tua sangat erat hubungannya dengan kepribadian anak setelah menjadi dewasa. Tujuan: mengetahui hubungan pola asuh orang tua terhadap perkembangan anak balita di Paud Permataku. Metode: Jenis penelitian yang digunakan dalam penelitian ini adalah penelitian analitik dengan pendekatan cross sectional study. Sampel berjumlah 54 responden. Analisis data yang digunakan yaitu analisis univariat dan bivariat. Hasil: tidak ada hubungan bermakna antara pola asuh orang tua dengan perkembangan anak balita. Kesimpulan: Diharapkan bagi tenaga pengajar agar dapat mengetahui lebih dalam mengenai perkembangan anak balita sehingga dapat memberikan stimulus yang tepat dalam setiap tahap perkembangan dalam proses belajar mengajar.
\end{abstract}

Kata Kunci: Perkembangan anak, pola asuh orang tua

The Relationship Between Parenting Style and the Development of Children Under Five in Paud Permataku Palu

\begin{abstract}
Background: The development experienced by children is a series of regular changes from one stage of development to the next stage which generally applies. Parents are a means for children to adapt to the environment and get to know the world around them as well as the patterns of interaction that apply in their environment. It happens due to parents are the basis for the child's personal formation. The forms of parenting are very closely related to the child's personality after becoming an adult. Objectives: to find out the relationship between parenting style and the development of children under five in PAUD Permataku. Method: Type of research used in this study is analytic research with a cross sectional study approach. The sample is 54 respondents. Data analyses used are univariate and bivariate analysis. Results: There was no significant relationship between parenting and the development of children under five. Conclusion: It is expected that teaching staff can find out more about the development of children under five so that they can provide the right stimulus at each stage of development in the teaching and learning process.
\end{abstract}

Keywords: child development, parenting style

\section{LATAR BELAKANG}

Pembangunan kesehatan sebagai bagian dari upaya membangun manusia seutuhnya antara lain diselenggarakan melalui upaya kesehatan anak yang dilakukan sedini mungkin sejak anak masih di dalam kandungan. Upaya kesehatan yang dilakukan sejak anak masih di dalam kandungan sampai lima tahun pertama kehidupannya, ditujukan untuk mempertahankan kelangsungan hidupnya sekaligus meningkatkan kualitas hidup anak agar mencapai perkembangan optimal baik fisik, mental, emosional maupun sosial 
serta memiliki intelegensi majemuk sesuai dengan potensi genetiknya. Untuk mencapai keberhasilan pembangunan kesehatan ini, peran serta keluarga sangat penting (Departemen Kesehatan Republik Indonesia, 2006).

Keluarga merupakan lingkungan primer bagi setiap individu sejak lahir sampai tiba masanya untuk meninggalkan rumah dan membentuk keluarga sendiri. Sebelum anak mengenal lingkungan yang lebih luas, terlebih dahulu anak mengenal lingkungan keluarganya melalui pengenalan normanorma dan nilai-nilai dalam keluarga untuk dijadikan bagian dari pribadinya. Oleh karena itu norma dan nilai yang berlaku dalam keluarga yang diturunkan melalui pendidikan dan bimbingan orang tua terhadap anakanaknya secara turun temurun (Soekanto, 2009).

Keluarga merupakan lembaga pertama dalam kehidupan seorang anak, tempat belajar segala sesuatu dan menyatakan diri sebagai mahluk sosial (Kartono, 1992; dalam Yusniah, 2008). Keluarga memiliki peran penting dalam pembentukan kepribadian seseorang. Dalam keluarga umumnya anak dan orang tua memiliki hubungan interaksi yang intim. Orang tua memberikan dasar pembentukan tingkah laku, watak, moral dan pendidikan anak.

Orang tua merupakan sarana bagi anak untuk beradaptasi dengan lingkungan dan mengenal dunia sekitarnya serta pola pergaulan hidup yang berlaku di lingkungannya. Ini disebabkan orang tua merupakan dasar pertama bagi pembentukan pribadi anak. Pola asuh orang tua erat hubungannya dengan perkembangan kesehatan emosional anak saat ini dan masa depan, keperibadian, karakter, kesejahteraan, perkembangan sosial dan kognitif, dan prestasi akademik (Howenstein, dkk., 2015).
Mengasuh anak di dalamnya terdapat pendidikan, sopan santun, membentuk latihan-latihan tanggung jawab dan sebagainya. Pola asuh yang positif dapat meningkatkan perilaku yang positif pada anak dan hal ini bermanfaat bagi perkembangan anak. Latar belakang orang tua, terutama pada karakteristik ibu seperti pendidikan, dukungan, dan usia dapat memengaruhi interaksi yang positif dengan anak (Kim, dkk., 2018). Salah satu faktor yang memengaruhi agresivitas pada anak adalah pola asuh dan perilaku orang tua terhadap anak (Hurlock, 2005).

Pola asuh yang diterapkan orang tua sangat bergantung pada bentukbentuk perilaku penyimpangan anak yang berawal dari masa balita. Orang tua dapat memilih pola asuh yang tepat untuk anaknya sejak masa balita. Orang tua yang salah menerapkan pola asuh sejak awal perkembangan masa balita akan membawa akibat buruk bagi perkembangan jiwa anak. Diharapkan orang tua dapat menerapkan pola asuh yang bijaksana atau menerapkan pola asuh yang tidak membawa kehancuran atau merusak jiwa dan watak seorang anak sejak masa balita (Ramadhan, 2009).

Jumlah balita di Indonesia sangat besar yaitu sekitar $10 \%$ dari seluruh populasi, maka sebagai calon generasi penerus bangsa, kualitas perkembangan balita di Indonesia perlu mendapat perhatian serius, dengan cara mendapat gizi yang baik, stimulasi yang memadai serta terjangkau oleh pelayanan kesehatan berkualitas (Kementrian Pemberdayaan Perempuan dan Perlindungan Anak dengan Badan Pusat Statistik, 2012).

Masa balita adalah masa emas dalam rentang perkembangan seorang individu. Pada masa ini, pertumbuhan fisik, perkembangan kecerdasan, keterampilan motorik dan sosial emosi berjalan demikian pesatnya. Masa balita juga merupakan masa 
kritis yang akan menentukan hasil proses perkembangan anak selanjutnya (Hurlock, 2005). Dalam masa perkembangan balita, anak mengalami perubahan yang terjadi dalam hal perubahan struktur dan fungsi tubuh yang lebih kompleks dalam kemampuan motorik kasar, motorik halus, bicara dan bahasa serta sosialisasi dan kemandirian (Soetjiningsih, 2010).

Balita memerlukan stimulasi perkembangan sedini mungkin dan terusmenerus untuk mencapai perkembangan yang optimal. Orang tua memiliki peranan yang sangat penting dalam memberikan stimulasi ini. Oleh karenanya, praktek pengasuhan yang optimal dari orang tua sangat diperlukan untuk meningkatkan perkembangan kecerdasan anak usia prasekolah. Kecerdasan yang dipengaruhi bukan hanya kecerdasan matematika dan bahasa saja tetapi semua kecerdasan (multiple intelegence) (Gunarsa, 2008).

Analisis mengenai profil dan perkembangan anak bermasalah hukum pada bagian ini dilakukan dengan menggunakan data narapidana anak/ anak pidana hasil registrasi Lembaga Pemasyarakatan (Lapas). Sedangkan analisis mengenai profil dan perkembangan anak korban tindak pidana dilakukan dengan menggunakan data anak korban tindak kejahatan/kriminalitas berdasarkan hasil registrasi Bareskrim (Bagian Reserse dan Kriminalitas) Kepolisian Republik Indonesia (Polri). Sesuai dengan laporan dari Kementerian Pemberdayaan Perempuan dan Perlindungan Anak dengan Badan Pusat Statistik (2012), jumlah anak nakal atau anak pelaku tindak pidana di seluruh Indonesia pada tahun 2011 mencapai sebanyak 54.712 anak. Sebanyak 51.400 anak $(94,0 \%)$ masih berstatus sebagai tahanan dan sebanyak 3.312 anak $(6,0 \%)$ lainnya telah berstatus narapidana atau anak didik. Anak laki-laki pelaku tindak pidana jumlahnya lebih banyak dibandingkan dengan anak perempuan. Jumlah anak nakal seluruhnya berjumlah sebanyak 54.712 anak yang mencakup sebanyak 52.276 anak laki-laki (sekitar 95,55\%) dan sebanyak 2.436 anak perempuan $(4,45 \%)$ (Kementrian Pemberdayaan Perempuan dan Perlindungan Anak dengan Badan Pusat Statistik, 2012).

Penelitian terdahulu melaporkan adanya hubungan yang sangat erat antara pola asuh orang tua dengan perkembangan anak balita. Saat penulis berada di tempat kerja, penulis banyak melihat pola asuh yang kurang tepat yang diterapkan oleh orang tua. Ada orang tua yang selalu mengikuti keinginan anaknya walaupun itu salah, ada orang tua yang selalu memaksakan anaknya untuk mematuhi aturan orang tuanya tanpa menghargai pendapat anaknya. Hasil wawancara dengan beberapa orang tua murid mereka mengatakan bahwa jika dari kecil salah mengasuh anak akan berpengaruh sampai anak tersebut menjadi dewasa. Menurut keterangan kepala sekolah PAUD Permataku, sikap dan kelakuan murid di PAUD Permataku berbeda-beda, ada anak yang suka memukul dan mengganggu temannya, ada yang suka bermain sendiri, ada yang manja untuk melakukan suatu pekerjaan atau aktivitas selalu bergantung pada teman atau guru yang ada. Jumlah murid yang ada di PAUD Permataku untuk kelompok TK 4-6 tahun sebanyak 39 anak, dan kelompok bermain 24 anak. Berdasarkan hal tersebut maka peneliti tertarik untuk mengidentifikasi hubungan pola asuh orang tua terhadap perkembangan anak balita di PAUD Permataku Palu.

\section{METODE}

Jenis penelitian yang digunakan dalam penelitian ini adalah penelitian analitik dengan pendekatan cross sectional study. Sebanyak 54 responden berpartisipasi 
dalam penelitian ini. Kriteria inklusi pada penelitian ini adalah orang tua dari balita yang aktif di PAUD Permataku, orang tua bersedia menjadi responden, orang tua ada saat pengambilan data dilakukan, dan balita dalam keadaan sehat. Pengambilan data dilakukan pada Agustus 2014.

Instrumen yang digunakan untuk menilai pola asuh menggunakan kuesioner yang telah digunakan pada penelitian sebelumnya oleh Sipahutar (2009). Kuesioner pola asuh ini dipisahkan berdasarkan pola asuh otoriter, demokratis dan permisif yang masing-masing terdiri atas 10 pernyataan dengan jawaban ya dan tidak. Responden diberikan kebebasan untuk memilih kuesioner berdasarkan pola asuh yang dijalankan tanpa mencantumkan bentuk pola asuh pada kuesioner tersebut. Berdasarkan pilihan kuesioner tersebut telah menggambarkan bentuk pola asuh yang dijalankan dalam mengasuh anaknya.

Instrumen untuk mengetahui perkembangan anak pada penelitian ini menggunakan Kuesioner Praskrining Perkembangan (KPSP) berdasarkan Departemen Kesehatan Republik Indonesia tahun 2006 untuk digunakan di tingkat pelayanan kesehatan primer sebagai salah satu upaya deteksi dini tumbuh kembang anak (Dhamayanti, 2006). Kuesioner ini dibuat berdasarkan umur balita. Pada kuesioner ini terdapat pertanyaan yang berisi kemampuan perkembangan anak, yang harus diisi oleh orang tua dengan jawaban ya dan tidak. Jika jawaban ya kurang dari 9 dicurigai adanya masalah (suspek), jika jawaban ya 9-10 dianggap tidak ada masalah (normal).

Data dianalisis secara univariat dan bivariat (chi-square test). Sebelum dilakuan pengambilan data, pada calon responden dijelaskan mengenai tujuan penelitian ini dan responden memberikan persetujuan. Peneliti menjaga kerahasiaan identitas responden dengan cara tidak mencantumkan nama responden pada kuesioner, hanya dengan menuliskan kode pada lembar pengumpulan data. Data penelitian ini hanya digunakan untuk keperluan penelitian. Responden berpartisipasi atas dasar kesukarelaan. Selain itu, semua informasi yang didapatkan dijamin kerahasiaannya oleh peneliti.

\section{HASIL \\ Karakteristik responden}

Karakteristik responden meliputi umur, pendidikan dan pekerjaan. Dari Tabel 1 diketahui bahwa umur responden terbanyak berusia 18-25 tahun, berpendidikan D1-D3, dan mempunyai pekerjaan sebagai Pegawai Negeri Sipil (PNS).

Tabel 1. Karakteristik Responden di PAUD Permataku Tahun 2014

\begin{tabular}{lll}
\hline Karakteristik & Frekuensi & Persentase (\%) \\
\hline $\begin{array}{lll}\text { Umur (tahun): } \\
\text { 18-25 }\end{array}$ & \\
$25-35$ & 32 & 59,3 \\
& 22 & 40,7 \\
\hline Pendidikan: & & \\
SMA & 14 & 25,9 \\
D1-D3 & 23 & 42,6 \\
S1-S2 & 17 & 31,5 \\
\hline Pekerjaan: & & \\
PNS & 24 & 44,4 \\
Polwan & 1 & 1,9 \\
IRT & 21 & 38,9 \\
Wiraswasta & 8 & 14,8 \\
\hline
\end{tabular}

Sumber: Data Primer, 2014

\section{Pola Asuh Orang Tua dan Perkembangan Anak}

Data terkait pola asuh orang tua dan perkembangan anak dapat dilihat di Tabel 2 . Berdasarkan tabel tersebut, paling banyak pola asuh orang tua adalah demokratis dan perkembangan anak dalam kategori sesuai. 
Tabel 2.

Pola Asuh Orang Tua dan Perkembangan Anak di PAUD Permataku

\begin{tabular}{lcc}
\hline Pola Asuh dan Perkembangan Anak & Frekuensi & Persentase (\%) \\
\hline Pola asuh: & 44 & \\
Demokratis & 10 & 1,5 \\
Tidak Demokratis & & \\
\hline Perkembangan anak: & 40 & 74,1 \\
Sesuai & 14 & 25,9 \\
Tidak sesuai & & \\
\hline
\end{tabular}

Sumber: Data Primer, 2014

Hubungan Antara Pola Asuh Orang Tua dengan Perkembangan Anak Balita

Tabel 3.

Hubungan Pola Asuh Orang Tua dengan Perkembangan Anak Balita

\begin{tabular}{lccccc}
\hline \multirow{2}{*}{ Pola Asuh Orang Tua } & \multicolumn{3}{c}{ Perkembangan Anak Balita } & \multirow{2}{c}{$\begin{array}{c}p \\
\text { value }\end{array}$} \\
\cline { 2 - 5 } & \multicolumn{4}{c}{ Sesuai } & \multicolumn{2}{c}{ Tidak Sesuai } \\
\cline { 2 - 6 } & $\mathrm{n}$ & $\%$ & $\mathrm{n}$ & $\%$ & \\
\hline Demokratis & 34 & 77,2 & 10 & 22,8 \\
\hline Tidak Demokratis & 6 & 60 & 4 & 40 & 0,424 \\
\hline
\end{tabular}

Sumber data: Primer

Tabel 3 menunjukkan bahwa perkembangan anak balita yang sesuai terbanyak terdapat pada orang tua yang memiliki pola asuh demokratis berjumlah 34 responden $(77,2 \%)$. Hasil uji Chi-Square nilai $p=0,424$ ( $p$ value $\geq 0,05$ ). Secara statistik tidak ada hubungan bermakna antara pola asuh orang tua dengan perkembangan anak balita.

\section{DISKUSI}

Hasil penelitian ini menunjukkan bahwa secara statistik tidak ada hubungan bermakna antara perkembangan anak balita dengan pola asuh orang tua. Menurut asumsi peneliti, hal tersebut disebabkan oleh kemungkinan kurangnya pemahaman orang tua terhadap pola asuh itu sendiri dan tidak dapat membedakan pola asuh yang diterapkan dalam mengasuh anaknya saat peneliti menyebarkan kuesioner dalam penelitian. Pemahaman yang kurang ini dapat memengaruhi hasil dari penelitian. Hal ini sesuai dengan pendapat Notoadmodjo (2007) yang menyatakan bahwa ada orang yang tingkat pengetahuan sebatas tahu saja.

Peneliti juga berasumsi bahwa tidak adanya hubungan antara pola asuh dengan perkembangan anak balita disebabkan oleh kurangnya pemberian stimulasi perkembangan terhadap anak balitanya, sedangkan di saat yang bersamaan orang tua menerapakan pola asuh yang tidak sesuai dengan perkembangan anak.

Anak merupakan sosok individu yang unik yang memiliki karakteristik yang berbeda dengan anak yang lainnya. Penerapan pola asuh yang tidak sesuai dengan tahap- 
an perkembangan anak kemungkinan disebabkan oleh meningkatnya pengetahuan orang tua tidak selalu diikuti oleh perilaku dengan kesadaran atau motivasi yang kuat dalam memberikan stimulasi perkembangan untuk perkembangan yang pesat. Orang tua mengetahui bahwa stimulasi penting dan bermanfaat bagi perkembangan anak balita namun belum tentu orang tua dapat mengerti dan memerhatikan perkembangan anaknya berdasarkan tingkatan umur balita. Pada setiap tahap perkembangan, terdapat beberapa aspek fisik dan psikologis yang terjadi, misalnya pada masa bayi secara umum menunjukkan bahwa anak sangat tergantung pada orang dewasa, sedangkan saat anak memasuki awal masa kanakkanak, ketergantungan mulai berkurang dan ada harapan serta perlakuan tertentu dari kelompok sosial serta mulai tumbuh kemandirian, yang akan berakhir saat anak mulai masuk sekolah dasar. Perkembangan pada setiap aspek memiliki tingkat dan kecepatan yang berbeda-beda baik tergantung dari faktor individu maupun lingkungan yang menstimulirnya. Seluruh perkembangan ini akan dilampaui anak dan setiap aspek perkembangannya tidak berdiri sendiri melainkan saling terkait satu sama lain.

Perkembangan anak serta kemampuan mereka dapat diidentifikasi lebih awal, yang selanjutnya dapat dikembangkan. Berbekal pemahaman tentang perkembangan anak balita maka orang tua atau orang dewasa lainnya dapat mengetahui titik terpenting untuk pengembangannya, dengan menitikberatkan pada masa belajar anak. Dengan perkembangan anak balita tersebut perlu diarahkan pada peletakan dasar-dasar yang tepat bagi perkembangan fisik, daya pikir, daya cipta, sosio-emosional, bahasa, komunikasi yang seimbang sebagai dasar pembentukan pribadi.
Peneliti berasumsi bahwa perkembangan anak dapat juga dipengaruhi oleh faktor lain selain pola asuh, seperti lingkungan, dan ekonomi. Lingkungan dapat berpengaruh terhadap perkembangan anak. Banyak stimulus yang diperoleh anak dari lingkungan tersebut turut memengaruhi perkembangan anak dan menciptakan persepsi yang baru konsep perkembangan anak. Ekonomi juga turut mempengaruhi. Anak yang dibesarkan di keluarga dengan ekonomi yang tinggi kebutuhan nutrisi anak akan terpenuhi dan sangat berpengaruh terhadap perkembangan anak, demikian pula sebaliknya.

Asumsi tersebut sejalan dengan pendapat Departemen Kesehatan Republik Indonesia (2006) yang menyatakan bahwa anak umumnya memiliki pola perkembangan normal yang merupakan hasil interaksi banyak faktor yang mempengaruhi perkembangan anak. Adapun faktor-faktor tersebut antara lain faktor dalam (internal) yang berpengaruh pada perkembangan anak, ras/etnik atau bangsa, keluarga, umur, jenis kelamin, genetik, kelainan kromosom. Faktor luar (eksternal), faktor prenatal, faktor persalinan, faktor pascasalin. Wong (2000) dalam Supartini (2004) menyatakan bahwa faktor-faktor yang memengaruhi perkembangan anak yaitu faktor herediter, ras atau suku bangsa dapat mempengaruhi perkembangan anak. Beberapa suku bangsa menujukan karakteristik yang khas, seperti suku Asmat di Irian Jaya secara turuntemurun berkulit hitam. Faktor lingkungan yang dapat memengaruhi pertumbuhan anak adalah lingkungan prenatal, pengaruh budaya lingkungan, status sosial dan ekonomi keluarga, nutrisi, iklim atau cuaca, olahraga/latihan fisik dan posisi anak dalam kelurga. Faktor internal, kecerdasan, pengaruh hormonal dan pengaruh emosi. Hal yang sama dengan yang dikemukakan oleh Soetjiningsih (2010) yang menyatakan 
bahwa status sosial ekonomi memengaruhi perkembangan anak.

Penelitian ini mempunyai beberapa keterbatasan, antara lain terkait instrumen pola asuh yang belum dilakukan uji validitas dan reliabilitas, penentuan pola asuh dalam dua kategori yaitu pola asuh demokratis dan tidak demokratis, dan jumlah sampel yang masih terbatas.

\section{SIMPULAN}

Berdasarkan hasil penelitian ini, diharapkan bagi tenaga pengajar di PAUD Permataku dapat mengetahui lebih dalam mengenai perkembangan anak balita sehingga dapat memberikan stimulus yang tepat dalam setiap tahap perkembangan dalam proses belajar mengajar. Bagi Instansi Poltekkes Kemenkes Palu, diharapkan dalam pendidikan keperawatan khususnya keperawatan anak dan keluarga perlu diadakan penekanan materi tentang tahapan perkembangan pada anak balita dan ciri-ciri pola asuh yang baik yang dapat diterapkan dalam mengasuh anak balita sehingga perawat dapat memberi informasi kepada keluarga, khususnya orang tua di lingkungan masyarakat.

Bagi peneliti berikutnya, diharapkan penelitian lebih lanjut untuk mengidentifikasikan faktor lain yang berhubungan dengan perkembangan dengan metode dan variabel yang berbeda serta menggunakan instrumen yang telah teruji valid dan reliabel. misalnya lingkungan, ekonomi, status sosial. Selain itu diharapkan bagi keluarga khususnya orang tua berperan sebagai wakil masyarakat yang harus mengajar anak bagaimana berperilaku yang sesuai dalam segala situasi kehidupan sehari-hari sehingga balita memiliki perkembangan yang baik. Hal inilah yang menjadikan setiap orangtua harus memahami setiap pola asuh sehingga dapat diterapkan dalam mendidik anaknya.

\section{DAFTAR PUSTAKA}

Departemen Kesehatan Republik Indonesia. (2006). Pedoman Pelaksanaan Stimulasi, Deteksi dan Intervensi Dini Tumbuh Kembang Anak Ditingkat Pelayanan Kesehatan Dasar. Jakarta: Departemen Kesehatan RI.

Dhamayanti, M. (2006). Kuesioner Praskrining Perkembangan (KPSP) Anak. Sari Pediatri, 8(1): 9-15.

Gunarsa, S. D. (2008). Psikologi Keluarga. Jakarta: PT BPK Gunung Mulia.

Howenstein, J., Kumar, A., Casamassimo, P. S., McTigue, D., Coury, D., Yin, H. (2015). Correlating parenting styles with child behavior and caries. Pediatr Dent, 37(1): 59-64.

Hurlock, E. B. (2005). Psikologi Perkembangan Suatu Pendekatan Sepanjang Rentang Kehidupan. Jakarta: Erlangga.

Kementrian Pemberdayaan Perempuan dan Perlindungan Anak dengan Badan Pusat Statistik. (2012). Profil Kesehatan Anak Indonesia 2012. Jakarta: Kementrian Pemberdayaan Perempuan dan Perlindungan Anak (KPP\&PA).

Kim, T. H. M., Connolly, J. A., Rotondi, M., Tamim H. (2018). Characteristics of positive-interaction parenting style among primiparous teenage, optimal age, and advanced age mothers in Canada. BMC Pediatrics, 18(2). doi:10.1186/s12887-017-0972-z

Notoatmodjo. (2007). Promosi Kesehatan dan IImu Perilaku. Jakarta: PT. Rineka Cipta.

Ramadhan, T. (2009). Pola asuh orang tua dalam mengarahkan perilaku anak. Retrieved from https://tarmizi.wordpress.com/2009/01/26/pola-asuhorang-tua-dalam-mengarahkanperilaku-anak/ 
Sipahutar, A. (2009). Pola Asuh Orang Tua Dan Tingkat Kebiasaan Remaja Dalam Mengkonsumsi Alkohol Di Desa Sirajaoloan Kec. Tarutung, Kab. Tapanuli Utara (Skripsi). Universitas Sumatera Utara, Medan, Indonesia.

Soekanto, S. (2009). Sosiologi Keluarga. Jakarta: PT. Rineka Cipta.

Soetjiningsih. (2010). Tumbuh Kembang Anak. Jakarta: EGC.
Supartini, Y. (2004). Buku Ajar Konsep Dasar Keperawatan Anak. Jakarta: Penerbit Buku Kedokteran EGC.

Yusniah. (2008). Hubungan Pola Asuh Orang Tua dengan Prestasi Belajar Siswa MTS Al-Falah Jakarta Timur (Skripsi). Fakultas IImu Tarbiyah Keguruan Universitas Syarif Hidayatullah, Jakarta, Indonesia. 